\title{
Art as the Creation of Nature Complex
}

\section{Dr. Raju Chitrakar}

HOD and Coordinator of MA Program in English, Tribhuvan University, Padmakanya Multiple Campus, Bagbazar, Kathmandu, Nepal

Received: 07 Nov 2020; Received in revised form: 14 Dec 2020; Accepted: 22 Dec 2020; Available online: 28 Dec 2020

(C)2020 The Author(s). Published by Infogain Publication. This is an open access article under the CC BY license

(https://creativecommons.org/licenses/by/4.0/).

\begin{abstract}
It has been thousands of years since literary art has been created. And there are diverse definitions on what literary art is and what its functions are. However, there is hardly any view on how literary art is produced. As a result, there are people who think that literary art is the product of mere idleness or fantasy and hence the world cannot get necessary benefit from it. When we know about the nature of artistic creation, people would not have any false belief about it like this. So the purpose of this article is to put forward a view on how literary art is created. It claims that literary art is created when one remains away from the elements of nature. And it is created to fulfil the sense of lack of nature in the conducts of human beings. When we know this nature of artistic creation, people would not take literary art as the creation of idleness. When it is well known, there could be established certain cannons of creating literary art and interpreting them. Then, it would be proved to be helpful in creating harmony in and between human being and nature.
\end{abstract}

Keywords-Ecocriticism, literary criticism, literary theories, Oedipus complex, nature, nature complex.

\section{INTRODUCTION}

Start of literary art can be traced as back as to the development of human society. Stories of success or failure were built then, no matter in the oral form. In the Western world, pieces of literary art were created long before philosophers started to produce philosophic thoughts in the fourth century BC. In the Eastern, especially Hindu world, the whole philosophic thoughts started with the creation of literary art. The Bedas, which are taken as the earliest records of the systematic thought, are written in the metrical form. Without any doubt, even these earliest works of literary art have contributed much in making peaceful, kind, loving conducts in Sanatanipeople.

A lots of literary artists and critics have expressed their views on literary art. Most of the literary critics before twentieth century expressed their views on the functions of literary art. And most of the literary critics of the twentieth century confined themselves on the subjects like means of literary creation and ways to interpret them; how meaning of an artistic creation is derived; how differently a male writer treats to the females in his work; how Western writers treat people of the third world; and how a healthy relation can be created between human being and nature. Different from these, the query of this article is what the motivating force behind artistic creation could be.

It is important to know the motivating force behind literary creation because without knowing how it is created, its purpose cannot be well known. And when its purpose is not known, respect to literary art from the audience cannot be expected. This is one of the reasons of many people taking literary art as a product of idleness that kills time not only of the producer but also of the reader. Somehow similar is the reason of the philosopher like Plato's not allowing any place to the poet, the representative of the literary artists, in his Republic. When one well knows how literary art is produced and what its functions are, one is likely to give first place to the literary art as he or she is the pathfinder of human life.

Argument of this article is that lack of the order of nature in the conducts of the fellow partners motivates a literary artist to produce his or her work of literary art. I have termed the tension that goes in the mind of the literary artist due to unnatural conducts in the fellow partnersas 'Nature complex'. His or her main purpose of producing the work of 
literary art is to show the need of taking the features of nature as the guide of molding human conducts. The word 'art' of the title indicates whole forms of art like painting, music, sculpture, etc. In deeper level all forms of art have this kind of objective. But in this article, the word has been delimited to 'literary art' to narrow down the coverage due to lack of space and knowledge of the whole forms of art.

To fulfil the objective of finding the motivating force behind artistic creation, first a brief synopsis of the practiced literary criticism and theories has been presented. Then some views on the motivating forces behind artistic creation have been brought. After it, role of nature behind artistic creation has been put. An example has been given by making a case study of artistic creation on William Blake's Poetical Sketches.Finally, conclusion has been supplied.

\section{A BRIEF SYNOPSIS OF LITERARY CRITICISM AND THEORIES}

Literary criticism started over two thousand years ago. Premodern critics, the critics before twentieth century, believed one way or other on the mimetic or pragmatic functions of art. For Plato, the poet makes imitations of realities"thrice removed from the truth" (18), and hence he is not useful for his Republic. However, his pupil Aristotle refuted him by saying that an artist imitates men in action and he is useful because he gives catharsis to the audience. By 'catharsis' he means outlet of some emotion or confusion by means of the knowledge or realization about some aspect of life acquired from the work of the dramatic art. In the view of the renaissance critic Philip Sidney, poet is a moral teacher for the better world. In the view of the neo-classical critics like John Dryden and Dr. Johnson, the function of a poet is to teach and give delight by representing the common world. By 'common world' they mean the standards of theircontemporary world.

However, the romantic critics appeared to be different from the earlier critics in the sense that in their view the primary task of the poet is not to teach but to express his or her feelings. The readers may get some knowledge from it indirectly. According to William Wordsworth, "passions of men are incorporated with the beautiful and permanent forms of nature and thus it should be basis of the study of the primary laws of human nature" (164).The expressions of feelings become a source of studying human nature because basic human natures are incorporated with nature.
Literary critics roughly from the beginning of the twentieth century can be taken to be modern as their emphasis is completely different from that of the critics before them. Neo-critics, formalists, structuralist critics, reader response critics, post-structuralist critics, feminist critics, post-colonial critics, ecocritics, may be included in the group of the modern critics. Neo-critics confined themselves in detecting the means of an artistic creation and the ways it should be evaluated. For them art should be objective and it should be created by using images and symbols that refer to some objects or ideas. And since a work of literary art is an independent entity, it should be evaluated independently too, without consulting the author's biography or context.

Somehow similar is the case with the formalist and structuralist critics. In the view of the formalist critics like Viktor Shklovsky, "The purpose of art is to impart the sensation of things as they are perceived and not as they are known. The technique of art is to make objects 'unfamiliar'" so that the reader is interested to the piece of art as he or she gets new sensation and thereby a new test in it (274). And thus a critic's job is to find how object of presentationhas been defamiliarizsed. Like them, in the view of the structuralist critics, a work of art has a definite structure. They assign the job of a critic as to analyze this structure. All these modern criticstake textas the central entity for meaning or interpretationone way or other.

However, love ofthe center diverts with reader oriented critics. To them meaning -the center- varies from reader to reader. They claim that readers' personal circumstance, including psychology and geographical as well as social contexts, influence their understanding or interpretation of a text. Post-structuralist critics also break the center. Jacques Derrida and Jacques Lacan, the prominent post-modern critics, studied language and concluded that it is semi-unconscious as it cannot carry full subject or truth. Like them, the feminist critics defuse the Western philosophy taking it as phallocentric one as they could not find them to have been equally treated as malesin it. Like them, the post-colonial critics refute Western literary values arguing that they are created to colonize the third world countries.

Since 1970s, however, there has emerged a new and influential approach of literary criticism known asecocriticism. It is a nature oriented approach to literary criticism. It studies human and nature relationship. Dominant human and nature relationship has been anthropocentric. However, ecocriticism pleads for non-anthropocentric 
approach to nature. It takes holistic approach of the world view. The practitioners of this approach tend to show interconnectivity between human being and nature. They have formulated the concept that "everything is connected to everything else" (Rueckert 110). David Pepper writes, "Ecocentrism views human kind as part of a global ecosystem, subject to ecological laws" (38). Similarly according to Frederick Turner, "Our bodies and brains are a result of evolution, which is a natural process so paradigmatic that it could almost be said to be synonymous with nature itself" (42). This implies that nature is connected even to the every functioning of human mind. And hence nature is connected to the creation of literary art as it is the product of creative mind.

\section{ROLE OF NATURE IN THE MOTIVATION FOR ARTISTIC CREATION}

Psychoanalysts and cultural critics appear to have hinted to the motivating force behind artistic creation. Sigmund Freud, known as the modern psychoanalyst, may be the first person who talked about the motivating factors behind artistic creation. He did this while bringing forth the basic principles of psychoanalysis. He divided mind into three parts: id, ego and super-ego. He related 'id' with the libidinal force, 'ego' with the controlling force, and 'super-ego' with the super conscious force. According to him, when a baby grows and enters into the symbolic world of father i.e. words, he or she is forced to suppress his or her oedipal desires-id including deep rooted love to the parent of opposite sex. As a result the baby gets fixation, to which Freud called 'Oedipus complex'in the case of son, and 'Electra complex' in the case of daughter. When ason grows adult, his desire to be in the oedipal world of mother is seen in his dream or in art if he has turned to be an artist. Freud writes, "A strong experience in the present awakens in the creative writer a memory of an earlier experience (usually belonging to his childhood) from which there now proceeds a wish which finds its fulfillment in the creative work" ("Creative Writers and Day-dreaming" 41). Thus, Freud takes 'Oedipus complex' as the source of artistic creation. It means that art is created to fill the lack of oedipal mother, who is the representative of nature in the wider sense.

However, this is not the case with many other psychoanalysts. Alfred Adler, for instance, emphasizes "strive for superiority" in the place of "Freud's emphasis on sexuality as the primary force motivating human behavior"
(Stevens 64). Like him, Michael Foucault, one of the cultural critics, takes power as the primary force motivating human behavior (Selden 201).

However, my position is different from them. I propose to take nature as the motivating force behind artistic creation. When a literary artist feels lack of thefeatures of nature in the conducts of his or her fellow partners, a kind of fixation is created within his or her mind. And this very fixation stimulates the literary artist to create literary art with his or her conscious or unconscious desire to fulfil the lack of the natural qualities in men. I call this fixation as 'Naturecomplex'. I have coined this phrase by taking some hint from Freud. Freud coined the term 'Oedipus complex' from Sophocles'Oedipus Rex. He described 'Oedipus complex' as the expression of the tension between sexual desire toward the parent of the opposite sex and submission to the parents (277). Similarly, by the phrase 'Naturecomplex' what I mean is the tension between the desire to live in the order of nature by following natural human qualities that are interconnected to the qualities of nature and lack of these in the practical lifeof the fellow partners. And by 'nature' one should not necessarily understand mere wilderness, but also nature based intrinsic human values like love, pity, peace, and so on.

To keep it in simple words, when a literary artist feels that his or her own desire or that of his or her fellow partners' and, in fact also of the fellow creatures' natural desires and right to live in the order of nature have been snatched by other fellow partners, he or she will fall ill of the 'Nature complex' and thereby be self-stimulated to create a piece of literary art against it to generate natural or nature coping qualities in their conducts. Similarly, if an artist is in the lap of nature or finds nature qualities human conducts, he or she may create art to express his or her happy feelings. Thus art has either defending mode -when the artist feels lack of nature in human conducts -or recreational mode when the artist is in nature or finds employment of natural human conducts in his or her fellow partners.

\section{A CASE STUDY OF AN ARTISTIC CREATION: BLAKE'S POETICAL SKETCHES}

William Blake is an author of several visionary and highly symbolic works. I have taken his Poetical Sketches to check the nature of artistic creation when an author feels lack of natural qualities in his or her fellow partners' conducts, and 
when he or she feels fulfilment of the natural qualities in their conducts. In the former state of affairs the artist finds his or her fellow partners and thereby him or herselfin the sad or fallen mode as the ultimate result of making opposite conducts from the order of nature and hence produces sad pieces of literary art symbolizing the need for human beings to live by following the order of nature.Similarly, in the latter state of affairs the author finds his or her fellow partners and thereby him or herself ultimatelyin the happy mode as the result of following the qualities or the order of nature and hence produces happy pieces of literary art.

By 'nature' I mean not only the qualities of nature but also natural human conducts. For Blake, love, mercy, pity,peace, truth, virtue, innocence are the qualities of nature. As the part of nature, these are also the natural qualities of human beings. When one does not find such natural qualities in one's conducts, he or she is fixated and is naturally stimulated to react for the fulfilment of natural qualities in one's conducts. If the person is a literary artist, he or she reacts accordingly by means of his or her literary art. So does Blake as a literary artistand engraver.

Blake's model of artistic creation can be seen in his "Gwin, King of Norway", one of the narrative songs of Poetical Sketches. In it, the narrator asks theaudience, mainly the kings, to hear his story of King Gwin, the king of Norway, who ruled tyrannically over the nations of the North: "The Nobles of the land did feed/ Upon the hungry poor;/ They tear the poor man's lamb, and drive/ The needy from their door!" (5-8). For Frued, the nobles would have oppressed the poor to win the love of women as he believes that the main reason behind the rivalry between father and son is to get the mother, symbolically women. But in Blake's above lines, the nobles would corrupt the poor for food, power and other lusts.

According to Freud, an oppressed son is passive to his father or society. He expresses his pre-oedipal desires not directly by being bold but indirectly and unconsciously by casting symbols. Freud writes, "We have found out that the distortion in dreams which hinders our understanding of them is due to the activities of censorship, directed against the unacceptable, unconscious wish-impulses" (125; ch. 10). According to Freud, symbolism is employed in myths and fairy tales, in popular sayings and songs, in colloquial speech and poetic fantasy (140).However, for Blake, the oppressed is active, not passive, and understands the hindrance created by the tyrannical ruler in living happily by following the order of nature and so he or she actively fights against the despot: "Pull down the tyrant to the dust,/ Let Gwin be humbled",/ They cry, "and let ten thousand lives/ Pay for the tyrant's head" (29-32). The oppressed people make voice against the oppressor because they are not passive.

For Blake, the tyrant cannot apply his reason to give up his tyranny as he is habitual to make unnatural andtyrannical rule on his citizens; and the suppressed people also cannot tolerate any tyranny. The result is open war between the two groups. King Gwin orders his soldiers to battle against the fury of his subjects: "And now the raging armies rushe'd,/ Like warring mighty seas;/ The Heav'ns are shook with roaring war,/ And dust ascends the skies!" (6972). Consequence of the war is destruction of the people, no matter armies or citizens: "The god of war is drunk with blood;/ The earth doth faint and fail;/ The stench of blood makes sick the heavens;/ Ghosts glut the throat of hell!" (9598). The earth and heavens are nothing but the natural people who feel sorrow on the deaths of men. They are sick to see the blood because it is unnatural in nature.

Michael Foucault, the prominent twentieth century historian of sociology, sees the control of power on art and whole people. Describing his view, Raman Selden writes, "Individuals working within particular discursive practice cannot think or speak without obeying the unspoken 'archive' of rules and constrains; otherwise they risk being condemned to madness or silence" (101). For Foucault, strive for is the motivating force behind human conducts. The artist and people either move for power or forced to remain silent from other power holders.However, this is not the case with Blake. For him power is defeated. He has shown the consequence of war in the same song. The king is defeated. The reason behind his defeat is that he left the natural path of love and help and became cruel, which is unnatural. Blake writes, "Those who are Cast out [from the heaven] are All Those who, having no Passion of their own because No Intellect, Have spent their lives in curbing \& Cruelty of all kings ...."(qtd. in Fyre 83). The king became cruel because he had no passion as he had no intellect. For Blake, passion is creative force. And creativity for him is intellectual or understanding, not rude or dark force.

For Blake, the victory of the suppressed described in the above song would not mean the creation of another tyranny but a return to nature. In "A War Song to Englishmen," the poet asks the soldiers to prepare holy war: "Soldiers, prepare! Our cause is heaven's cause;/ Soldiers, prepare! Be worthy of our cause:/ Prepare to meet our father in the sky:/ Prepare, O troops, that are to fall today! (21-24). 
The soldiers are not the king's soldiers but the fighters against any kind of unnatural activities that hinder people's right to live happily by employing natural qualities in their conducts. For Blake, Heaven is nothing but living happily by applying natural qualities.

In the "Song by a Young Shepherd," the shepherd is happy to live in nature and asks others to join him: "When the painted Birds laugh in the shade,/ Where our tables with cherries and nuts is spread;/ Come live and be merry and join with me;/ To sing the sweet chorus of ha, ha, he" (13-16). The shepherd is in his happy mode. He is happy not alone: he is happy when he finds the whole nature, the trees, the green hills, the green meadows, the grasshopper, the birds laughing and his friends singing. When the shepherd is happy as others are happy and asks others to come and sing with him, he is in his natural stateof love and innocence with no any worry. His state is like that of Adam, the happy first man according to the Bible. For Blake, earth itself is heaven. And, for him, God is not outside but within as it is nothing but imagination (Frye 30). The shepherd is able to live in the heavenly state because he is in the natural state.

For Blake, one becomes able to live in such a heavenly world and be happy when one follows truth, virtue and innocence, which are the features of both nature and human nature. In the "Song by an Old Shepherd", the old shepherd says the same: "Whilst virtue is our walking -staff/ And Truth a lantern to our path,/ ... Innocence is a winter's gown;/ So clad, we'll abide life's pelting storm/ That makes our limbs quake, if our hearts worm" (5-12). Winter is the symbol of difficulties of life. The old shepherd suggests that one should face natural difficulty innocently, from which life becomes still warm and pleasing. Innocence can be the gown of winter in the sense that it makes one able to face the difficulties innocently. The old shepherd knew it from his experience. From this Blake has hinted necessary movement of an experienced person to nature, as truth, virtue and innocence are the features of nature or of the natural state of human being.

Blake writes the story of the King's defeat not for his own advantage but to show bad consequences of one's being cruel, which is an unnatural human activity. $\mathrm{He}$ is stimulated to write so because he has passion or energy, the creative force, and falls ill of nature complex, the tension created from the lack of natural qualities in the conducts of his fellow partners, the king of the above story being their representative. He has nature complex not necessarily because he was himself suppressed, but also because he could not see others' sufferings, no matter known or unknown, of this or that place. And hence, by implication, this nature complex becomes the motivating force for one's artistic creation, as to Blake, which is created to fill the lack of nature in the conducts of people.

\section{CONCLUSION}

As human being is one of the member species of nature, there is strong connectivity between human being and nature. As per the conducts of human beings, nature castspositive or negative results on human beings. If a literary artist sees his or her fellow partners making conducts that are not as per the features of nature, he or she cannot tolerate. As a result he or she becomes the patient of naturecomplex, which stimulates him or her to produce a piece of literary art that shows the need of making nature coping human conducts. The case study made on some poems of Blake's Poetical Sketches perfectly reflects this nature of literary creation. Blake wrote the narrative song "Gwin, King of Norway" to give knowledge to the tyrants or others who suppress others' natural desire and right to live by following natural qualities thatthey are sure to fall. And so they have to make natural conducts with their fellow partners. To show the need of such a transformation in the conducts of people is the purpose of literary art.

From these,it can be reasoned that the motivating force behind artistic creation is 'naturecomplex' -the fixation or tension in the mind of a literary artist between his or her expectation to get nature related human conducts like love, pity, peace, cooperation, etc. from the fellow partners and getting just opposite conducts like hatred, suppression, disorder, selfishness, and so on from them.The artist produces his or her work of literary art indicating the need for human beings to live by following the order of nature. When an artist is in the lap of nature or sees or gets nature coping conducts in the fellow partners, he or she produces art that representshappy feelings of his or her characters indicating for the readers to live by applying natural qualities in their lives. If we make deep study, we can find such a modelapplied in all sorts of literary art one way or other as in Blake's poems.

Thus, responsibility of an art critic is to bring into light the lack or fulfilment of the natural values indicated in the work of the literary art which motivated the artist knowingly or unknowingly to create his orher literary work. From such a great job of the art critics, natural or nature 
coping human values would be brought into light, which would, then, be adopted by people in the affairs of their lives. And this in turn would help in establishing peace, stability and developmentnot only in human being but also between human being and nature in the true sense.

\section{REFERENCES}

[1] Blake, William. The Complete Writings of William Blake. Ed. Geoffery Keynes. Memvill, nd.

[2] Freud, Sigmund. Introductory Lectures on Psychoanalysis. 2nd ed. Trans. Joan Riviers. George Allen, 1952.

[3] ..., "Creative Writers and Day-dreaming". 20th Century Literary Criticism. David Lodge, ed. Longman, 1972, pp. 3642.

[4] Fyre, Northrop. Fearful Symmetry: A Study of William Blake. Princeton UP, 1947.

[5] Papper, David. Modern Environmental Ethics. Rutledge, 1996.

[6] Plato. The Republic[Book 6].The Theory of Literary Criticism from Plato to the Present. Ed. Raman Selden. Longman, 1988, pp. 12-18.

[7] Ruckert, William. "Literature and Ecology". The Ecocriticism Reader. Eds. CheryllGlotfelty and Harold Fromm. Georgia UP, 1996, pp. 105-123.

[8] Selden, Raman. A Reader's Guide to Contemporary Literary Theory. 2nd ed. Harvester, 1989.

[9] Stevens, Richard. Freud and Psychoanalysis: An Exposition and Appraisal. Open UP, 1983.

[10] Shklovsky, Victor. "Art as Technique." The Theory of Literary Criticism from Plato to the Present. Ed. Raman Selden. Longman, 1988, pp. 274-276.

[11] Turner, Frederick. "Cultivating the American Garaden". The Ecocriticism Reader. Eds. CheryllGlotfelty and Harold Fromm. Georgia UP, 1996, pp. 40-51.

[12] Wordsworth, William. "Preface to Lyrical Ballads". English Critical Texts: 16th Century to $20^{\text {th }}$ Century. Eds. D. J. Enright and Ernst de Chichera. Oxford UP, 1996. 